\title{
Circulating leptin and its muscle gene expression in Nellore cattle with divergent feed efficiency
}

\author{
Lúcio Flávio Macedo Mota ${ }^{1,2}$, Cristina Moreira Bonafé , Pâmela Almeida Alexandre ${ }^{3}$, Miguel Henrique Santana ${ }^{3}$, \\ Francisco José Novais ${ }^{3}$, Erika Toriyama ${ }^{4}$, Aldrin Vieira Pires ${ }^{1}$, Saulo da Luz Silva ${ }^{5}$, Paulo Roberto Leme ${ }^{5}$, \\ José Bento Sterman Ferraz ${ }^{3}$ and Heidge Fukumasu ${ }^{3^{*}}$
}

\begin{abstract}
Background: Leptin has a strong relation to important traits in animal production, such as carcass composition, feed intake, and reproduction. It is mainly produced by adipose cells and acts predominantly in the hypothalamus. In this study, circulating leptin and its gene expression in muscle were evaluated in two groups of young Nellore bulls with divergent feed efficiency. Individual dry matter intake (DMI) and average daily gain (ADG) of 98 Nellore bulls were evaluated in feedlot for $70 \mathrm{~d}$ to determinate the residual feed intake (RFI) and select 20 animals for the high feed efficient (LRFI) and 20 for the low feed efficient (HRFI) groups. Blood samples were collected on d 56 and at slaughter (80 d) to determine circulating plasma leptin. Samples of Longissimus dorsi were taken at slaughter for leptin gene expression levels.
\end{abstract}

Results: DMI and RFI were different between groups and LRFI animals showed less back fat and rump fat thickness, as well as less pelvic and kidney fat weight. Circulating leptin increased over time in all animals. Plasma leptin was greater in LRFI on $56 \mathrm{~d}$ and at slaughter $(P=0.0049)$. Gene expression of leptin were greater in LRFI animals $(P=0$. 0022) in accordance with the plasma levels. The animals of the LRFI group were leaner, ate less, and had more circulating leptin and its gene expression.

Conclusion: These findings demonstrated that leptin plays its physiological role in young Nellore bulls, probably controlling food intake because feed efficient animals have more leptin and lower residual feed intake.

Keywords: Beef cattle, Energy homeostasis, Fat depositon, Residual feed intake

\section{Background}

Leptin is a polypeptide hormone produced mainly by adipose cells [1], being also expressed by other tissues such as skeletal muscle [2], mammary gland [3], and others [4]. The main physiological function of leptin is energy homeostasis by controlling feed intake by inhibiting hunger [5-7]. It acts on a specific receptor (LEPR) in the brain, most specific to the hypothalamus in ventromedial, dorsomedial, and arcuate nuclei [8]. Although the physiological role of leptin is to control food intake, obese individuals generally present greater circulating

\footnotetext{
* Correspondence: fukumasu@usp.br

${ }^{3}$ Departamento de Medicina Veterinária, Faculdade de Zootecnia e Engenharia de Alimentos, Universidade de São Paulo, Av. Duque de Caxias Norte $n^{\circ} 225$, Pirassununga 13635-900, SP, Brazil

Full list of author information is available at the end of the article
}

levels of the hormone due to their greater percentage of body fat [9]. Obese people usually present resistance to leptin by alterations in the LEPR signaling and/or diminished crossing into the blood brain barrier [10].

Fat metabolism and deposition is important for livestock, affecting the quality of the products (beef, milk, etc) and providing energy reserves for reproduction and lactation [11]. Soon after the discovery of the obese gene in 1994 [1], its product, leptin, was identified for potential applications in animal production [12]. Indeed, research has been done on different aspects of leptin in livestock, including the use of its polymorphisms in animal breeding programs [13-17] and the use of circulating plasma leptin as a predictor of body composition $[18,19]$. 
In sheep, plasma concentration of leptin is more related to variation in body fatness $(35 \%)$ than to nutritional status (17\%) [20]. Corroborating this result, leptin levels in beef cattle (Bos taurus) were positively associated with adipose cell size [21], body fatness [22], and with the $12^{\text {th }}$ rib and rump fat thickness, explaining $16.8 \%$ of the variation in the $12^{\text {th }}$ rib fat thickness [19]. In the same work, the authors [19] showed the circulating leptin was positively associated with residual feed intake (RFI), a measure of feed efficiency, however, they explained very little of the variation in RFI $(<3.2 \%$ of the variance). A moderate association $(r=0.31)$ of leptin with RFI was also showed by Richardson et al. [23] in Angus steers.

In Bos indicus, the majority of beef cattle grown in Brazil, Leptin gene polymorphisms were associated mostly with growth and carcass traits [17, 24, 25], but no study was found on the circulating plasma leptin and/or muscle gene expression association with feed efficiency. Thus, the aim of this work was to characterize the circulating plasma leptin and its muscle gene expression in young Nellore bulls with divergent residual feed intake.

\section{Methods}

\section{Animals and experimental design}

A feeding trial of 98 Nellore bulls (16 to 20 months old and $376 \pm 29 \mathrm{~kg} \mathrm{BW}$ ) was conducted at the Faculdade de Zootecnia e Engenharia de Alimentos, Universidade de São Paulo (FZEA / USP), Pirassununga, SP, Brazil. All the details regarding animals, traits, and diet can be found in Alexandre et al. [26]. Briefly, the data collection period consisted of $70 \mathrm{~d}$ preceeded by $21 \mathrm{~d}$ of adaptation to diet and environment. Animals were weighed in the beginning, the end, and every $14 \mathrm{~d}$ of the experimental period. Additionally, daily dry matter intake (DMI) for each animal was measured by weighting the orts every day. Residual feed intake (RFI) was calculated [27], and two groups were formed: low RFI (LRFI) and high RFI (HRFI), each composed of 20 extreme animals.

\section{Plasmatic leptin quantification}

Plasma samples were collected at $56 \mathrm{~d}$ of feeding trial and at slaughter $(80 \mathrm{~d})$ by jugular venipuncture using vacutainer tubes containing sodium heparin as anticoagulant (BD Vacutainer Plus, BD, Brazil). All blood samples were centrifuged at $3,500 \times \mathrm{g}$ for $15 \mathrm{~min}$ at $4{ }^{\circ} \mathrm{C}$, and plasma was collected and stored at $-20{ }^{\circ} \mathrm{C}$ until assayed for leptin. The concentration was determined in duplicate $100 \mu \mathrm{L}$ aliquots of plasma samples, using the leptin RIA kit (Multi-species leptin RIA kit, Cat. \# XL-85 K, Millipore, St. Charles, MO, USA) and following the manufacturer's instructions. Intra and interassay
CVs for the leptin assay were less than $10 \%$ as described by Delavaud et al. [20].

\section{Slaughter and tissue sample collection}

Animals were slaughtered on $\mathrm{d} 80$ at the Experimental slaughterhouse of University of São Paulo, after fasting from feed for $16 \mathrm{~h}$. Immediately after slaughter, samples of the medial portion from the right Longissimus lumborum muscle (between the $12^{\text {th }}$ and $13^{\text {th }}$ ribs) were taken from 10 animals of each RFI group. The samples were collected and immediately immersed in RNA stabilization solution (RNAholder - Bioagency, São Paulo/SP, Brazil). The sample were maintained overnight at $4{ }^{\circ} \mathrm{C}$ and then stored at $-80{ }^{\circ} \mathrm{C}$ until RNA extraction.

\section{Gene expression of Leptin}

Total RNA was extracted from $300 \mathrm{mg}$ of powdered tissue samples using Trizol reagent following the manufacturer's protocol (Invitrogen, Carlsbad, CA, USA). After quantification in a spectrophotometer, $1 \mu \mathrm{g}$ of total RNA was treated with DNAse (Invitrogen, Carlsbad, CA, USA) and reverse transcribed into cDNA using Go Script ${ }^{\mathrm{TM}}$ Reverse Transcription System kit (Promega Corporation, Madison, WI, USA). Real time-PCR was performed on a CFX ConnectTM Real-Time PCR detection system (Bio-Rad, Hercules, CA, USA), using SYBR Green RT-PCR kit (Applied Biosystems, Foster City, CA, USA) with the following cycle parameters: $95^{\circ} \mathrm{C}$ for 3 min and 40 cycles at $95{ }^{\circ} \mathrm{C}$ for $10 \mathrm{~s}$ and $60{ }^{\circ} \mathrm{C}$ for $30 \mathrm{~s}$. Primers utilized for PCR were leptin (F) 5'GGGCACGTCAGCATCTATTA3' and leptin (R) 5'CCTGTCTGCTGTTATGGTCTTA3', and for the endogenous control, the ribosomal 18S (F) 5'CCTGC GGCTTAATTTGACTC3' and 18S (R) 5'AACTAAGAACGGCCATGCAC3' were used. The amplification efficiency was 0.90 to 0.99 for leptin and 18S, respectively. All reactions were performed in triplicate, and the method of Livak and Schimttgen was used for gene expression analysis [28].

\section{Statistical analysis}

All analyses were performed using GraphPad Prism version 6.0 for Mac (GraphPad Sotware, La Jolla California, USA). The phenotypic measures assessed in the LRFI and HRFI groups were first tested for Gaussian distribution by the Shapiro-Wilk test, and later, they were tested for difference between the means of the groups by Student's t-test for normal distributed data and Mann-Whitney-Wilcoxon test for nonparametric data. The correlation between the two leptin measures was performed with the Pearson test. A two-way ANOVA followed by the Fisher post-test was used for leptin plasmatic concentration on d 56 and d 80. Statistically significant results were considered when $P<0.05$. 


\section{Results}

\section{Characterization of feed efficiency groups}

Phenotypic traits (related to body weight, feed efficiency, muscle and fat deposition, liver weight, and cascass yeld), are already published and no significant difference of sire or age on RFI was found [26]. Animals of LRFI and HRFI groups showed no difference in body weight (initial, final, or average daily gain) and rib eye area (initial, final, and gain). On the other hand, DMI and RFI were different between groups, wherein LRFI animals presented less DMI [26]. In addition, LRFI animals presented less fat deposition in both back fat and rump fat and less pelvic and kidney fat relative weight in comparison with HRFI. Thus, LRFI animals eat less and are leaner than HRFI animals [26].

\section{Circulating plasma leptin and muscle gene expression}

The correlation between those two measures was moderate to strong and significant $(r=0.5817$ and $P=0.0071)$. In this experiment, leptin concentration in plasma increased over time in both groups (Fig. 1a), accounting for $21.3 \%$ of the total variation and was considered significant $(P<0.0001)$. In addition, leptin concentration was different between groups $(P=0.0049)$. However, no interaction between time and groups was noted though $(P=0.513)$.

Leptin gene expression was performed in muscle samples collected at slaughter. LRFI animals showed greater expression of leptin $(P=0.0022)$ compared to HRFI animals, reflecting the increased leptin plasma concentration of animals at slaughter (Fig. 1b).

\section{Discussion}

In this study, it was shown that circulating plasma leptin and muscle gene expression were greater in high feed efficiency group (LRFI) than in low feed efficiency group (HRFI) of Nellore bulls. In addition, feed efficient animals showed less fat deposition, probably a consequence of significant less DMI. In a previous work from the group, it was demonstrated that LRFI animals have less circulating plasma cholesterol at the end of the feeding trial [26]. Since the main role of leptin is regulate food intake in different species [29-31], these results support the physiological role of this hormone in Nellore cattle, since leptin is controlling DMI, plasma cholesterol, and fat deposition. Supporting this concept, less efficient animals have less muscle gene expression and circulating leptin which increases DMI, plasmatic cholesterol, and fat deposition.

Nonetheless, in other experiments on cattle, leptin concentration was positively associated with DMI, body fat, and RFI $([19,23,32]$. In these cases, leptin seems to be related to body fat mass but not with the control of food intake. Interestingly, this phenotype resembles the resistance to leptin in obese humans where even elevated levels

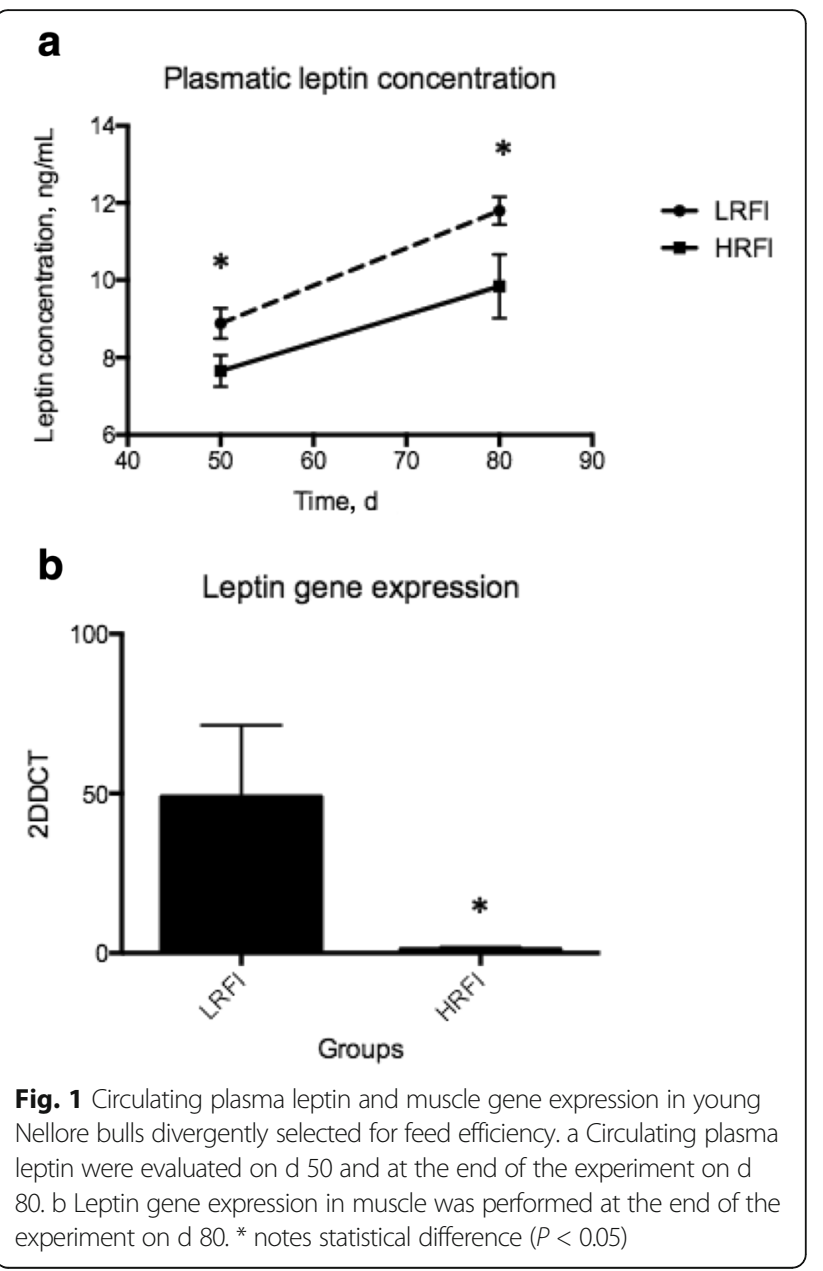

of leptin produced by greater percentage of body fat failed to control hunger and modulated body fat [33]. In accordance with the hypothesis, a recently published work from Foote et al. [34] suggested that beef cattle on a high grain finishing ration could become slightly leptin resistant.

The opposing results observed in the current study and others suggest the hypothesis that animals in this experiment are not in an "obese" phenotype, being instead where leptin reflects fat body mass. This could be explained by the conjunction of: (1) having used young bulls while others used steers [18, 19, 23, 34] or heifers [34, 35] and/or; (2) Nellore is an indicine breed and most experiments on cattle are performed in taurine breeds. The first possibility is probably the most relevant since the effect of sex on fat deposition has long been described. Total rate of fat deposition relative to muscle is similar for heifers and steers but significantly lower in bulls [36]. These authors concluded that differences in fattening patterns among sexes result from a combination of fattening at a lighter weight of carcass muscle in heifers than steers and in steers than bulls, in addition 
to a more rapid rate of fat deposition relative to muscle in heifersand steers compared to bulls. In addition, the effect of sex is well known to be related to feed efficiency, where bulls are more efficient than steers or heifers [37, 38]. In humans, females have greater circulating leptin as compared to males, even after the correction for differences in body fat mass [39]. In vitro experiments with human adypocytes in primary culture showed that both testosterone, and its biologically active metabolite dihydrotestosterone inhibited leptin secretion up to $62 \%$, supporting that sex is clearly a relevant factor on leptin metabolism [39].

One should also consider the possible effect of genetic differences between Nellore and taurine breeds for the observed effect in this experiment. Indicine cattle are known to be more adapted to tropical climate but with less growth performance than taurine breeds. Corroborating this idea, Marcondes et al. [40] demonstrated the dry matter intake and performance of steers were higher in Nellore crossbreds (NelloreSimmental and Nellore-Red Angus) than that of pure Nellore, however, no difference in feed efficiency was noted between groups. Paschal and colleagues [41] studying the postweaning and feedlot growth and carcass characteristics of five indicine breeds and one taurine (Angus) showed that Zebu crosses (including Nellore) grew faster postweaning and were heavier and taller than Angus crosses. However, the Angus cross was more desirable in marbling score and quality grade. Beef products derived from Nellore are recognized by the international market as very lean meat due to lack of intramuscular fat [42]. The same authors demonstrated the difference in intramuscular fat content in skeletal muscle of Nellore and Angus cattle is due to a slightly enhanced muscle adipogenesis in Angus cattle. Altogether, these results support the concept that Nellore have diferent growth curves in comparison to taurine breeds taking more time for fat deposition.

Therefore, it is plausible that the increased muscle gene expression of leptin and circulating leptin levels in feed efficient young Nellore bulls in comparison to less efficient animals, although, others demonstrated the opposite. This result also calls attention for the use of leptin as a possible predictor for body fat mass in cattle, especially if considered for use in Nellore cattle.

\section{Conclusion}

To the best of our knowledge, this work demonstrated for the first time that leptin plays its physiological role in young Nellore bulls, rather its pathological role, controlling food intake because feed efficient animals have more circulating leptin and lower residual feed intake.

\section{Abbreviations}

ADG: Average daily gain; BWf: Final body weight; BWg: Body weight gain BWi: Initial body weight; DMI: Dry matter intake; HRFI: Low feed efficient; RBg: Rib eye gain; REAf: Final rib eye area; REAi: Initial rib eye area; RFI: Residual feed intake; RIA: Radioimmunoassay; LEPR: Leptin receptor; LRFI: High feed efficient

\section{Acknowledgements}

We would also like to thank Michael James Stablein of the University of Illinois Urbana-Champaign for his translation services and review of this work.

\section{Funding}

This work was financially supported by "Fundação de Amparo à Pesquisa do Estado de São Paulo" (FAPESP 2010/05650-5; 2014/02493-7, 2014/07566-2).

\section{Availability of data and materials}

The datasets used and/or analyzed during the current study are available from the corresponding author on reasonable request.

\section{Authors' contributions}

PAA, CMB, SLS, PRL, and HF designed the experimental study; LFMM and CMB performed the leptin circulating analysis; PAA, MHS, LFMM, and HF conducted the in vivo experiment and sample collection; ET helped LFMM on gene expression analysis; LFMM, PAA, FJN, and HF drafted the manuscript. All authors read, made critical revisions, and approved the final manuscript for submission.

\section{Ethics approval and consent to participate}

All animal protocols were approved by the Institutional Animal Care and Use Committee of Faculdade de Zootecnia e Engenharia de Alimentos, Universidade de São Paulo (FZEA-USP - protocol number 14.1.636.74.1).

Consent for publication

Not applicable.

\section{Competing interests}

The authors declare that they have no competing interests.

\section{Author details}

${ }^{1}$ Departmento de Zootecnia, Universidade Federal dos Vales do Jequitinhonha e Mucuri, Diamantina, MG 39100-000, Brazil. ²Present adress: Faculdade de Ciências Agrárias e Veterinárias, Universidade Estadual Paulista, Jaboticabal, SP 14884-900, Brazil. ${ }^{3}$ Departamento de Medicina Veterinária, Faculdade de Zootecnia e Engenharia de Alimentos, Universidade de São Paulo, Av. Duque de Caxias Norte n²25, Pirassununga 13635-900, SP, Brazil. ${ }^{4}$ Departmento de Zootecnia e Desenvolvimento Agrossocioambiental Sustentável, Faculdade de Veterinária, Universidade Federal Fluminense, Niteroi, RJ 24230-340, Brazil. ${ }^{5}$ Departamento de Zootecnia, Faculdade de Zootecnia e Engenharia de Alimentos, Universidade de São Paulo, Pirassununga 13635-900, SP, Brazil.

Received: 3 March 2017 Accepted: 7 August 2017

Published online: 01 September 2017

\section{References}

1. Zhang $Y$, Proenca R, Maffei M, Barone M, Leopold L, Friedman JM. Positional cloning of the mouse obese gene and its human homologue. Nature. 1994;372:425-32.

2. Wang T, Hartzell DL, Flatt WP, Martin RJ, Baile CA. Responses of lean and obese Zucker rats to centrally administered leptin. Physiol Behav. 1998;65:333-41.

3. Bonnet M, Gourdou I, Leroux C, Chilliard Y, Djiane J. Leptin expression in the ovine mammary gland: putative sequential involvement of adipose, epithelial, and myoepithelial cells during pregnancy and lactation. J Anim Sci. 2002:80:723-8

4. Margetic S, Gazzola C, Pegg G, Hill R. Leptin: a review of its peripheral actions and interactions. Int J Obes. 2002;26:1407-33.

5. Elias CF, Aschkenasi C, Lee C, Kelly J, Ahima RS, Bjorbaek C, et al. Leptin differentially regulates NPY and POMC neurons projecting to the lateral hypothalamic area. Neuron. 1999;23:775-86. 
6. Fekete C, Légrádi G, Mihály E, Huang QH, Tatro JB, Rand WM, et al. Alpha-Melanocyte-stimulating hormone is contained in nerve terminals innervating thyrotropin-releasing hormone-synthesizing neurons in the hypothalamic paraventricular nucleus and prevents fasting-induced suppression of prothyrotropin-releasing hormone ge. J Neurosci. 2000:20:1550-8

7. Houseknecht KL, Portocarrero CP. Leptin and its receptors: regulators of whole-body energy homeostasis. Domest Anim Endocrinol. 1998:15:457-75.

8. Fei H, Okano HJ, Li C, Lee GH, Zhao C, Darnell R, et al. Anatomic localization of alternatively spliced leptin receptors (Ob-R) in mouse brain and other tissues. Proc Natl Acad Sci U S A. 1997;94:7001-5.

9. Considine RV, Sinha MK, Heiman ML, Kriauciunas A, Stephens TW, Nyce MR, et al. Serum immunoreactive-leptin concentrations in normal-weight and obese humans. N Engl J Med. 1996;334:292-5.

10. Lubis AR, Widia F, Soegondo S, Setiawati A. The role of SOCS-3 protein in leptin resistance and obesity. Acta Med Indones. 2008;40:89-95.

11. Wylie ARG. Leptin in farm animals: where are we and where can we go? Animal. 2011;5:246-67.

12. Hossner KL. Cellular, molecular and physiological aspects of leptin: potential application in animal production. Can J Anim Sci. 1998;78:463-72.

13. Buchanan FC, Fitzsimmons CJ, Van Kessel AG, Thue TD, Winkelman-Sim DC, Schmutz SM. Association of a missense mutation in the bovine leptin gene with carcass fat content and leptin mRNA levels. Genet Sel Evol. 2002;34:105-16

14. Lagonigro R, Wiener P, Pilla F, Woolliams JA, Williams JL. A new mutation in the coding region of the bovine leptin gene associated with feed intake. Anim Genet. 2003;34:371-4.

15. Schenkel FS, Miller SP, Ye X, Moore SS, Nkrumah JD, Li C, et al. Association of single nucleotide polymorphisms in the leptin gene with carcass and meat quality traits of beef cattle. J Anim Sci. 2005:83:2009-20.

16. Nkrumah JD, Li C, Yu J, Hansen C, Keisler DH, Moore SS. Polymorphisms in the bovine leptin promoter associated with serum leptin concentration, growth, feed intake, feeding behavior, and measures of carcass merit. J Anim Sci. 2005;83:20-8.

17. Silva DBS, Crispim BA, Silva LE, Oliveira JA, Siqueira F, Seno LO, et al. Genetic variations in the leptin gene associated with growth and carcass traits in Nellore cattle. Genet Mol Res. 2014;13:3002-12.

18. Nkrumah JD, Keisler DH, Crews DH, Basarab JA, Wang Z, Li C, et al. Genetic and phenotypic relationships of serum leptin concentration with performance, efficiency of gain, and carcass merit of feedlot cattle. J Anim Sci. 2007:85:2147-55

19. Foote AP, Hales KE, Kuehn LA, Keisler DH, King DA, Shackelford SD, et al. Relationship of leptin concentrations with feed intake, growth, and efficiency in finishing beef steers. J Anim Sci. 2015;93:4401-7.

20. Delavaud C, Bocquier F, Chilliard Y, Keisler DH, Gertler A, Kann G. Plasma leptin determination in ruminants: effect of nutritional status and body fatness on plasma leptin concentration assessed by a specific RIA in sheep. J Endocrinol. 2000;165:519-26.

21. Delavaud C, Ferlay A, Faulconnier Y, Bocquier F, Kann G, Chilliard Y. Plasma leptin concentration in adult cattle: effects of breed, adiposity, feeding level, and meal intake. J Anim Sci. 2002:80:1317-28.

22. Brandt MM, Keisler DH, Meyer DL, Schmidt TB, Berg EP. Serum hormone concentrations relative to carcass composition of a random allotment of commercial-fed beef cattle. J Anim Sci. 2007;85:267-75.

23. Richardson EC, Herd RM, Archer JA, Arthur PF. Metabolic differences in Angus steers divergently selected for residual feed intake. Aust J Exp Agric. 2004:44:441.

24. da Silva RCG, Ferraz JBS, Meirelles FV, Eler JP, Balieiro JCC, Cucco DC, et al. Association of single nucleotide polymorphisms in the bovine leptin and leptin receptor genes with growth and ultrasound carcass traits in Nellore cattle. Genet Mol Res. 2012;11:3721-8.

25. de Oliveira JA, da Cunha CM, do A CB, de O SL, ARM F, de P NG, et al. Association of the leptin gene with carcass characteristics in Nellore cattle. Anim Biotechnol. 2013;24:229-42.

26. Alexandre PA, Kogelman $L A$, Santana MHA, Passarelli D, Pulz LH, FantinatoNeto $\mathrm{P}$, et al. Liver transcriptomic networks reveal main biological processes associated with feed efficiency in beef cattle. BMC Genomics. 2015;16:1073.

27. Koch RM, Swiger LA, Chambers D, Gregory KE. Efficiency of feed use in beef cattle. J Anim Sci. 1963;22:486-94.
28. Livak K, Schmittgen TD. Analysis of relative gene expression data using real-time quantitative PCR and the 2(-Delta Delta C(T)) method. Methods. $2001 ; 25: 402-8$

29. Halaas JL, Gajiwala KS, Maffei M, Cohen SL, Chait BT, Rabinowitz D, et al. Weight-reducing effects of the plasma protein encoded by the obese gene. Science. 1995;269:543-6.

30. Larsson H, Elmståhl S, Berglund G, Ahrén B. Evidence for leptin regulation of food intake in humans. J Clin Endocrinol Metab. 1998;83:4382-5.

31. Henry BA, Goding JW, Alexander WS, Tilbrook AJ, Canny BJ, Dunshea F, et al. Central administration of leptin to ovariectomized ewes inhibits food intake without affecting the secretion of hormones from the pituitary gland: evidence for a dissociation of effects on appetite and neuroendocrine function. Endocrinology. 1999;140:1175-82.

32. Minton JE, Bindel DJ, Droullard JS, Titgemeyer EC, Grieger DM, Hill CM. Serum leptin is associated with carcass traits in finishing cattle. J Anim Sci. 1998;76:231.

33. Myers MG, Leibel RL, Seeley RJ, Schwartz MW. Obesity and leptin resistance: distinguishing cause from effect. Trends Endocrinol Metab. 2010;21:643-51.

34. Foote AP, Tait RG, Keisler DH, Hales KE, Freetly HC. Leptin concentrations in finishing beef steers and heifers and their association with dry matter intake, average daily gain, feed efficiency, and body composition. Domest Anim Endocrinol. 2016:55:136-41.

35. Kelly AK, McGee M, Crews DH, Fahey AG, Wylie AR, Kenny DA. Effect of divergence in residual feed intake on feeding behavior, blood metabolic variables, and body composition traits in growing beef heifers. J Anim Sci. 2010:88:109-23.

36. Berg RT, Jones SDM, Price MA, Hardin RT, Fukuhara R, Butterfield RM. Patterns of carcass fat deposition in heifers, steers and bulls. Can J Anim Sci. 1979;59:359-66.

37. Hedrick H. Bovine growth and composition. Research Bulletin Monograph 928. Washington, DC: Agricultural Experimental Station, 1968; pp. 56.

38. Bailey CM, Probert CL, Bohman VR. Growth rate, feed utilization and body composition of young bulls and steers. J Anim Sci. 1966;25:132-7.

39. Wabitsch M, Blum WF, Muche R, Braun M, Hube F, Rascher W, et al. Contribution of androgens to the gender difference in leptin production in obese children and adolescents. J Clin Invest. 1997;100:808-13.

40. Marcondes M, Valadares Filho S, Oliveira I, Veiga P, Paulino R, Ferreira R, et al. Eficiência alimentar de bovinos puros e mestiços recebendo alto ou baixo nível de concentrado. Brazilian J Anim Sci. 2011:406:1313-24.

41. Paschal JC, Sanders JO, Kerr JL, Lunt DK, Herring AD. Postweaning and feedlot growth and carcass characteristics of Angus-, gray Brahman-, Gir-, Indu-Brazil-, Nellore-, and red Brahman-sired F1 calves. J Anim Sci. 1995;73:373-80.

42. Martins TS, Sanglard LMP, Silva W, Chizzotti ML, Rennó LN, Serão NVL, et al. Molecular factors underlying the deposition of intramuscular fat and collagen in skeletal muscle of Nellore and Angus cattle. PLoS One. 2015;10:e0139943.

\section{Submit your next manuscript to BioMed Central and we will help you at every step:}

- We accept pre-submission inquiries

- Our selector tool helps you to find the most relevant journal

- We provide round the clock customer support

- Convenient online submission

- Thorough peer review

- Inclusion in PubMed and all major indexing services

- Maximum visibility for your research

Submit your manuscript at www.biomedcentral.com/submit
) Biomed Central 